\title{
Yeterli ve sağlıklı gıda temininde Veteriner Hekimliğin önemi ve Veteriner Kontrol Araştırma Enstitülerinin rolü
}

\author{
Özcan Yıldırım ${ }^{10}$, Cevdet Yaralı2 (), Erdem Danyer ${ }^{3}$ () \\ 1,2,3 Veteriner Kontrol Merkez Araştırma Enstitüsü Müdürlügü, Ankara, Türkiye
}

Geliş Tarihi / Received: 31.05.2020, Kabul Tarihi / Accepted: 04.06.2020

\begin{abstract}
Özet: İklimden ekonomiye, hemen her alanda hızla küreselleşen dünyada, aynı zamanda büyük bir sosyo-kültürel ve sosyo-ekonomik değişim yaşanmaktadır. Artan nüfus ve kentleşme, gıda da israf ve tekelleşme, kaynakların ve kırsal nüfusun azalması, kirlilik, hastalık ve zararlıların artması; yeterli ve sağlıklı gıdaya erişimi, her geçen gün zorlaştırmaktadır. Bu tehdit, tüm toplumların öncelikli sorunlarının başında gelmektedir.

İşte bu süreçte, büyük ferasetle kurulan kurumlara ve tarihsel rollerine ihtiyaç duyuyoruz. Veteriner Kontrol Araştırma Enstitüleri, bu kurumlarımızdan bazısı olup; bu çalışmamızda Cumhuriyetimizin kuruluş sürecindekine benzer şekilde, en çok gereksinim duyduğumuz gıda güvencesi ve arzındaki rolü hakkında, tarihe yazılı bir not düşmek arzusundayı.

Gündemdeki SARS-CoV-2 (Covid-19) küresel salgının bizlere dikte ettiği, "üretimde kendi kendimize yeterlilik" gerçeği; en büyük ev ödevi olarak karşımızda durmaktadır. Bu gerekçelerimiz ve kurumsal rolümüzü, hakkıyla yerine getirme gaye ve gayretini bir kez daha ifade etme adına bu derlemeyi hazırlamış bulunmaktayız.
\end{abstract}

Anahtar kelimeler: Aşı, gıda güvenliği ve güvencesi, halk sağlığı, veteriner hekimlik, veteriner kontrol enstitüsü

\section{The role of Veterinary Medicine and Veterinary Control Research Institutes in the food security and supply chains}

\begin{abstract}
World is globalizing rapidly in many areas from climate to economy, nevertheless there is also a great socio-cultural and socio-economic changes. Access to adequate and healthy food makes it difficult every day due to increasing population and urbanization, food waste and monopolization, reduction of resources and rural population, increase of pollution and diseases. This threat is the primary problem of all societies.

In this time, we are seeking institutions and their historical roles which were established with great discernment. Veterinary Control and Research Institutes are some of these institutions. In this study, we want to explain these institute's role in the food security and supply chains when we need them the most.

The fact that the global epidemic dictated us by the SARS-CoV-2 (Covid-19) on the agenda is the "self-sufficiency in production" fact; stands before us as the biggest homework. We have prepared this review in order to once again express our motives and efforts to fulfill our justifications and institutional role.
\end{abstract}

Key words: Food safety and security, public health, vaccination, veterinary control institute, veterinarian

\section{Giriş}

Gıda güvencesi, insanların beslenmesi için gerekli olan gıdanın yeterli üretimi, çiftlikten sofraya kadar güvenli bir şekilde arzı, fiziksel ve ekonomik erişimi ve bu durumun sürdürebilirliğini temel alan dört ayak üzerine oturmaktadır (FAO, 1996).

Gıda güvencesinin olmayışının başlıca sebepleri kuraklık, sel gibi iklimsel afetler, savaş, ekonomik politikalar kaynaklı kriz ve kıtlıkların yanı sıra; gıda güvencesinin bir parçası olan gıda sağlığı ve güvenliğinin yeterince sağlanamamasına bağlı sorunlardır. Örneğin tarihsel süreçte sığır vebası, şap gibi viral pandemiler hayvansal gıdaya ulaşımı önemli ölçüde sınırlamıştır.
İnsanın sağlıklı bir şekilde yaşamını sürdürebilmesi; yeterli, dengeli ve sağlıklı gıda ile beslenmesiyle mümkündür. Vücut tarafından sentezlenemeyen, ancak beslenme ile dışarıdan alınması gereken esansiyel aminoasitler olarak adlandırılan aminoasitlerin dengeli bir şekilde alınabilmesi için hayvansal kökenli proteinlerin tüketilmesi zorunludur. Hayvansal proteinlerin biyolojik değerliliği bitkisel kaynaklı gıdalara göre çok daha yüksektir. Ayrıca, vücuda emilimi, kullanımı ve yararlanılması açısından hayvansal gidalar insana en uygun kompozisyonda bulunmaktadır.

Gıda güvencesi, yani "gıda arzı kapasitesi", moda tabirle "nükleer güç ile eşdeğer" değil, mevcut 
en büyük güçtür. Konu temel olarak üç başlık altında incelenecektir.

\section{Gıda Güvencesinde Veteriner Hekimlik}

Gıda güvencesi kapsamında, hayvansal gıdaların yeterli ve ekonomik üretiminde veteriner hekimlik, çok önemli rol almaktadır. Çiftlik hayvanlarında ıslah faaliyetleri, hayvanlarda yeterli ve dengeli besleme ve hayvan refahıyla verimlilik artırımaktadır. Verimlilikle birlikte, başta aşılama olmak üzere koruyucu hekimlikle sağlanan birey ve sürü sağlığı ve sürü yönetimiyle, yeterli ve sürdürülebilir hayvansal gıda üretimi sağlanabilmektedir.

Veteriner Hekimlik faaliyetleri, iyi tanımlanarak planlanmış kurumsal bir organizasyon eşliğinde hayvan sağlığı ve halk sağlığını koruyarak ve gıda güvencesini sağlayarak, aynı zamanda bir ekonomik faaliyet olması hasebiyle de hayvansal üretimin verimliliğini yükselterek bir katma değer artışı sağlamaktadır.

Bir toplumda gerçek anlamda gıda güvencesinden bahsetmek "kendi kendine yeterlilik" ile mümkündür. Günümüz koşullarında kendi kendine yeterlilik, sınırlı sayıda ve tekelleşen oluşumlarla değil; ancak kamunun desteği ve hakemliğinde, aile çiftçiliğinin etkin şekilde varlığını sürdürebilmesi ile mümkün olabilecektir.

Aile çiftçiliği, başka bir deyişle; "tüm yumurtaları ayn sepete koymama", bir intiyat stratejisidir. Ülkemiz, sahip olduğu iklimsel ve coğrafi çeşitlilik, yani diğer bir ifadeyle onlarca farklı havzaya sahip oluşu ile üretimde çeşitliliği ve sürekliliği sağlamada büyük bir avantaja sahiptir. Olası ambargo, kıtlık, doğal afet, ekonomik krizlerde üretim yapan on binlerce aile çiftliği, kendi kendine yeterliliğin en büyük ispatı ve can simididir. Dünya genelinde ticarete konu olan gıdaların sevk ve idaresi büyük oranda tekelleşme yoluyla yönetiliyorsa da toplumların temel gıda ihtiyaçlarının \%80'i halen aile çiftçiliğine bağlı olarak sağlanabilmektedir (FAO-IFAD 2019).

Günümüzde, aile çiftçiliğinin sürdürebilirliği için sağlanacak kamu gücünün etkin desteği, gerçek anlamda veteriner hekimlik organizasyonunun varlığı, yetkinliği ve desteği ile mümkün olacaktır. Örneğin üretim planlaması, hedeflenen verimlilik artışı, pazarlama stratejisi, birey ve sürü sağlığı, sürü yönetimi, kayıt sistemleri, izlenebilirlik, sağlıklı birincil ve ikincil ürün üretimi, koruyucu hekimlik faaliyetleri gibi çok önemli süreçler, ancak iyi bir kamu ve sivil toplum kuruluşu birlikteliğiyle sağlanabilmektedir.

Bugün, küresel boyuttaki tekelleşme nedeniyle gıda arzının bireysel çabalarla sağlanabilmesi müm- kün görünmemektedir. Ancak kamu otoritesi organizasyonuyla sahip olunan kurumsal varlıkların oluşturulması ve gücüyle mümkün olabilmektedir.

Büyük ekonomik ve siyasi krizler, küresel salgınlar ve doğal afetler göstermiş̧ir ki başta gıda güvencesi ve sağlık gibi alanlar olmak üzere, stratejik sektörlerin kamu veya kamu ortaklığı ile yürütülmesi bir zorunluluktur. Geçmiş̧e bu politikaları tamamen terk eden ülkelerin ise bu alanlarda hızla, en azından ortaklıkla kamulaştırmaya gittiği görülmektedir Bunu yapamayan ülkeler ise çok uluslu küresel şirketlere tam bağımlı hale gelmişlerdir.

Toplumların gıda güvencesinde veteriner hekimlik, çok önemli görevler üstlenmektedir. Veteriner hekimlerin bireysel yeterlilik ve yetkinliği ile bunun pozitif bir kuvvete dönüştürülmesi, bağımsız ve tanımları, stratejileri, planlamaları çok iyi yapılmış kurumsal bir teşkilat ile mümkün olabilecektir. Tüm bu gerekçelerle, veteriner hekimlik mesleği ve kurumsal organizasyonları, büyük önem arz etmektedir.

\section{Gıda Güvenliğinde Veteriner Hekimlik}

Gıda güvenliği, gıda güvencesinin en önemli ayağıdır. Bu nedenle gıdaların her türlü üretim aşaması, nakliyesi, depolanması, kontrolü ve son tüketiciye kadar sunulması sürecinde, gıda kaynaklı rahatsızlıklara ya da hastalıklara sebep olan fiziksel, biyolojik ve kimyasal nitelikteki çeşitli risk unsurlarını önleyecek, zararsız kılacak ya da ortadan kaldıracak yaklaşımları içeren bir kavram olarak tanımlanmaktadır.

Gıda güvenliğinin temeli, sağlıkı gıda arzıdır. Dünya Sağlık Örgütü (DSÖ) sağlıklı gıdayı özetle, beş temel prensiple izah etmektedir. Bunlar:

a. Gıdaları insanlar, hayvanlar ve biyolojik ajanların neden olduğu kirlilikten korumak.

b. Pişirilmiş gıdalardaki kirliliği önlemek için, çiğ ve pişmiş gıdaların birbirine temasını engellemek.

c. Patojenleri yok etmek için, gıdaları uygun sıcaklıkta ve uygun sürede pişirmek.

d. Gıdaları uygun sıcaklıkta saklamak.

e. Ham maddeleri ve suyu korumak.

"Çiftlikten çatala gıda güvenliği", ifadesi bu kavramı kısaca özetlemektedir. Çiftlikten çatala gıda arzı zincirinde, veteriner hekimlik ve kurumsal organizasyonu hayati rol oynamaktadır. Birleşmiş Milletler Çevre Programı (UNEP) Ofisinin tespitiyle, zoonoz kavramı, hayvan ve/veya hayvansal kökenli gıdalardan insana, insandan hayvana bulaşabilen hastalıklar olarak tanımlanmaktadır ve insanlarda bulaşıcı hastalıkların yaklaşık \%60'ı, yeni ortaya çıkan bula- 
şıcı hastalıkların yaklaşık \% $75^{\prime} \mathrm{i}$ zoonoz hastalıklardır (UNEP 2016).

Kuduz, şarbon, bruselloz, tularemi, kistik ekinokokkozis, toksoplazmoz, zoonotik tüberküloz, salmonelloz gibi zoonozlar eskiden beri bilinen hastalıklardır. Son 15-20 yılda bu enfeksiyonların yansıra, zoonotik karakterli yeni enfeksiyonlar ortaya çıkmış ve etkileri her an devam etmektedir. Bunların başında, Şiddetli Akut Solunum Yolu Sendromu-2 (SARS-CoV-2, Covid-19), Şiddetli Akut Solunum Sendromu (SARS), Ebola Virus Hastalığı, Batı Nil Virusu Enfeksiyonu, Avian influenza (kuş gribi), Domuz Gribi, Deli Dana Hastalığı (BSE), Orta Doğu Solunum Sendromu (MERS), Zika Virus Hastalığı (ZVH), Kırım-Kongo Kanamalı Ateşi vs. gibi hastalıklar ilk akla gelen zoonozlardır. Bu kadar çok fazla riskin olduğu hayvansal gıda üretiminde, sağlıklı gıda arzı, tüm insanlık için hayati önem arz etmektedir.

Sağlıklı üretimin birinci yolu koruyucu hekimliktir. Veteriner hekimlik mesleği, hayvan refahına yönelik hizmetleri, hastalık teşhisi, analizi ve tedavisi, sağlıklı beslenme, beslenme hastalıklarının tedavisi, mera yönetimi, korunması ve ıslahı, reprodüksiyon ve suni tohumlama ile sağlıklı üreme faaliyetleri, koruyucu aşılamalar, bilimsel sürü yönetimi, işletme, kesimhane ve hayvansal ürün işleme tesislerinde denetim, kayıt ve kontrolleri ile verimli ve sağlıklı hayvan ve dolayısıyla güvenli gıda üretiminin gerçekleştirmesinde çok önemli görevler üstlenmektedir.

\section{Veteriner Kontrol Araştırma Enstitülerinin Rolü}

Ülkemizde veteriner hekimlik mesleğinin eğitimi, dünya ile başat bir şekilde 1842 yılından beri sürdürülmektedir (Beşe 1981). Illk veteriner mektebi 1849 yılında Osmanlı Hükümeti zamanında açılmıştır (Bekman 1940). Bu durum, mesleği, kurumsallaşma ve bilimsel değer üretme anlamında çok avantajlı kılmış ve 178 yıldır toplumumuza gıda güvencesi ve sağlıklı gıda arzında hizmet veren bir meslek haline dönüştürmüştür.

1900 'lü yıllarda büyük bir ferasetle kurulmaya başlanan Veteriner Kontrol Araştırma Enstitüleri, savaşta, salgın afetlerinde ve bu ülkenin Kurtuluş Savaşı sürecinde hayati rol oynamıştır (Bekman 1940). Bu yılların başında kuduz aşısı üretilmiş, dünyayı kasıp kavuran sığır vebasına karşı anti-serum ve ardı sıra sığır vebası aşısı bulunarak, hastalıkla mücadelede başarılı olunmuştur. Devam eden yıllarda şap, şarbon, brusella, mavidil, koyun-keçi vebası, koyun-keçi çiçek aşısı, kanatlı aşıları vs. başta olmak üzere onlarca hastalığa karşı aşı, anti serum ve biyolojik test kitleri üretilmiştir (Çizmen 1960; Özsoy 1962, 1964, 1967).
O dönemlerde yetişen, Mehmet Akif Ersoy, Ziya Gökalp, Selahattin Batu, Mehmet Turan Yarar, Kemal Cemil, Süreyya Tahsin Aygün, Osman Nuri Koçtürk, Adil Mustafa Şehzadebaşı, Ahmet Şefik Kolaylı ve daha nice meslek büyükleri; tarihsel süreçte sağladıkları toplumsal yarar, halk sağlığı, gıda güvenliği ve gıda güvencesinde; isimleri, toplumsal hafızada mütevazı bir şekilde yer edinmiştir. Bu üstatlarımız ve daha ismini anamadığımız nice meslek büyüklerinin ayrı ayrı hikâyeleri var. Sadece, Etlik Veteriner Kontrol Merkez Araştırma Enstitüsünün de kurucusu olan Ahmet Şefik Kolaylı için yazılan bir anekdotu örnek vermek, yeterli diye düşünüyoruz:

Balkan savaşı sırasında askerlerin beslenmesi bozuk ve özellikle proteince yetersizdir. Öte yandan, sığır vebası hayvanlar arasında salgın halindeydi. Hastalığa yakalanan sığırlara bir şey yapılamıyor ve bunlardan yararlanılamıyordu. Sığır vebasının insanda hastalık yapmadığını bilen genç Veteriner Teğmen Şefik hastalanan hayvanların kesilmesini ve bunların etlerinin kavrularak askere yedirilmesini teklif etti. Bu öneri, hasta hayvan etinin insanlara yedirilemeyeceği itirazıyla reddedildi. Bunun üzerine genç veteriner, " Bu hayvanları yiyen tek bir insanda hastalık çıkarsa beni kurşuna dizin "diye diretti ve önerisini kabul ettirdi. Böylece askerlerin protein ihtiyacı karşıland. Edirne'nin Bulgarlardan kurtarlmasında bu direnişin hiç etkisi olmadığını kimse öne süremez (Unat 1976).

Ülkemizde, mevcut durumda birisi şap hastalığı konusunda ihtisaslaşmış olmak üzere, toplamda dokuz veteriner kontrol araştırma enstitüsü bulunmaktadır. Kuruluşlarından beri çeşitli reorganizasyonlar geçirmekle beraber bu kurumlarımız, günümüze kadar taşıdıkları tarihsel hafızaları ve kısıtlı imkânlarıyla, görevlerini yerine getirmeye devam etmektedir. Bu enstitülerimiz, Ankara, İstanbul, İzmir, Erzurum, Samsun, Konya, Adana ve Elazığ illerinde olmak üzere, sekiz coğrafi bölgeye stratejik olarak konumlanmış ve yetkilendirilmişlerdir (TOB 2020).

Enstitülerimizin dört temel görevi bulunmaktadır:

1. Araştırma-Geliştirme (Ar-Ge) görevleri: Hayvan sağlığı, halk sağlığı ve çevre sağlığı halkasında araştırma ve geliştirme faaliyetlerinde bulunmak.

2. Teşhis ve kontrol hizmetleri: Teşhis, test, analiz, muayene, nekropsi ve diğer teşhis hizmetlerini yürütmek.

3. Eğitim Faaliyetleri: Ulusal ve uluslararası eğitim faaliyetlerini yapmak ve organize etmek.

4. Üretim (Aşı, anti serum ve biyolojik test kitleri üretimi): Ülkemiz ihtiyacı olan bulaşıcı ve salgınlara karşı aşı ve anti serum üretimi ve teşhis hizmet- 
lerinde kullanılan alerjenlerin ve kitlerin üretimi gerçekleştirmek.

Enstitülerimiz konumları itibariyle, hızlı müdahale ve kolay ulaşılabilirlik açısından, bölgesel olarak hizmet vermelerinin yanı sıra, bazı enstitüler altyapıları dâhilinde, ulusal ve/veya uluslararası hastalık ve/ veya konu referanslığı görevlerini de üstlenmişlerdir.

Etlik Veteriner Kontrol Merkez Araştırma Enstitüsü kuruluşundan itibaren gıda maddelerinin kontrolü konusunda da hizmet vermektedir (Çizmen 1960). Burada başta hayvansal gıda maddeleri olmak üzere çeşitli gıda maddelerinin ve içme sularının mikrobiyolojik muayeneleri Uluslararası Standartlar Teşkilâtı (ISO), Türk Standartları Enstitüsü (TSE) ve Dünya Hayvan Sağlığı Örgütü (OIE) metotları vb. uluslararası geçerliliği olan metotlarla yapılmaktadır. Kuduz ve leptospirozis gibi hastalıkların teşhisleri konusunda Sağlık Bakanlığı'na da hizmet vermekte, genetik ve doping kontrolü gibi alanlarda hem ulusal hem de uluslararası düzeyde analiz hizmetleri yürütmektedir.

\subsection{Veteriner Hekimler, gıda güvencesinde birer Uç Beyliği'dir.}

Gerek kamuda gerekse özel mesleki icra alanında; ülkenin en ücra köşelerine kadar hizmetleri götüren bir organizasyona sahip meslek; hiç şüphesiz veteriner hekimliğidir. Ülkenin her noktasında var olan bu meslek; icra makamlarının, eylem planlarını gerçekleştirmesinde de çok önemli görevler üstlenmektedir.

Enstitüler, bir nevi uç beyliği olan sahadaki kamu ve serbest veteriner hekimlerin hastalık ve zararlılar ile mücadelesinde karşılaştığı her türlü sorunun çözümünde, ihtisas ve referans noktalarıdır. Sahadan gelen numuneler, en modern metotlarla incelenerek mücadele stratejileriyle birlikte raporlanmaktadır. intiyaç olması durumunda, sahaya derhal uzman desteği sağlanmaktadır. Bilindiği üzere, bulaşıCı ve salgın hastalıklarda tedavi her zaman mümkün olmadığı gibi ekonomik bir seçenekte olmayabilmektedir. Özellikle kitlesel sürü sağlığında, koruyucu hekimlik; en akılcı, kestirme ve ekonomik yoldur. Yüzyılı aşkın bilgi, tecrübe birikimi ve kurumsal hafızaları ile Enstitülerimiz, Türkiye'nin ihtiyaç duyduğu aşı, anti-serum ve biyolojik ürünleri üretmeye yine yüz yılı aşkın bir süredir devam etmektedir.

\subsection{Veteriner Kontrol Araştırma Enstitüleri, sağlıklı gıda arzı sürecinde, birer tahmin ve erken uyarı merkezleridir}

Küresel iklim değişikliği, ulaşımın kolaylaşması ile artan insan, hayvan ve ürün-hammadde hareket- leriyle son yıllarda vektör (kene, sinek, bit, pire vb.) ve yabani hayvanlarla hastalıkların da bir yerden bir yere bulaşması kolaylaşmıştır (Hacioglu 2017). Bu hastalıklara örnek olarak, hanta virüs, mavidil, zika, batı nil virüsü, Kırım-Kongo kanamalı ateşi, akabane, afrika at vebası, sıtma, veba, tularemi, lyme verilebilir. Bu hastalıklarla mücadelede erken teşhis, yayılma durumlarının tespiti ve izlenmesi son derece önemlidir. Enstitülerimizce yürütülen projelerle, vektörel hastalıklarla mücadele için ülke genelinde birçok bölgeye kurulan sinek tuzaklarıyla ve buralardan düzenli alınan numunelerin incelenmesiyle, bu biyolojik ajanların ülkemizde olup olmadığı tespit edilebilmektedir. Yaban hayatından çiftlik hayvanlarına ve insanlara bulaşabilen birçok hastalık, yine enstitülerimiz tarafından izlenmektedir. Enstitülerimiz, bu tespitleriyle; tedbir alma adına birer tahmin ve erken uyarı merkezleridir.

Bakanlığın, uzman veteriner hekimlerin tespit ve önerileri doğrultusunda belirlediği politikalar dâhilinde, klinik ve/veya sero-surveylerle tarama yapılarak hastalıkların varlığı ve seyri takip edilmektedir. Hayvansal gıda üretiminin başlıca kaynakları olan sığır, koyun ve kanatlı yetiştiriciliğinde sürü taramaları, koruyucu hekimliğin erken uyarı rolüyle, çok büyük bir başarısı olup, işletme ve dolayısıyla ülke ekonomisine önemli katkılar sağlanmaktadır.

Sahada seyreden hastalık etkenlerinin, modern metotlarla izolasyonu ve identifikasyonu yapılarak, teşhis konulmakta ve hastalık mücadelesi en etkili şekilde yapılabilmektedir. Özellikle viral etkenlerde, virüslerin gen dizilemesi ve filogenetik analizleri yapılarak, hızlıca aşı veya anti serum üretimi yapılmakta ve bunların geliştirilmesine çalışılmaktadır. Örneğin, çok sayıda serotipe sahip şap virüsü, mavidil virüsü, newcastle virüsü, avian influenza virusu vs. gibi bazı hastalıklarla mücadelede, bu alt tiplerinde belirlenmesi gerekmektedir.

\subsection{Veteriner hekimlik ve özelinde de Enstitülerimiz, gıda arzında; "çiftlikten çatala" yolculuğunun tüm zincirinde vardır ve olmak zorundadır}

Veteriner hekimlik, eğitim altyapısının ve kurumsal organizasyonunun gücü oranında ve bu organizasyon içerisinde de tarihsel hafızaları ile varlığını sürdürecek olan Veteriner Kontrol Araştırma Enstitüleri; yeterli ve sağlıklı gıda temininde, "güçlü toplum" ve "güçlü devlet"in temel dinamiklerinden birisi olarak, görevlerini sürdürmeye devam edecektir.

İfade edilen bilgiler ışığında, bugün Dünya'da karşı karşıya kalınan en büyük problemler aşağıda özetlenmiştir. 
a. İklim değişikliği: İnsanoğlunun bitmek tükenmek bilmeyen hırsı ve tüketim çılgınlığı, dünyayı çok ciddi çevresel ve atmosferik kirliliğe maruz bırakmıştır. Bu kirlilik ve sınırlı olan doğal kaynakların hızla tüketilmesi, beraberinde ekolojik dengenin alt üst olmasına neden olmuş; buna bağlı olarak kuraklık, sel felaketleri, susuzluk ve küresel ısınma gibi iklim değişiklikleriyle, gıda arzı ve güvenliği; yakından ve derinden etkilenmiştir.

b. Vektörel hastalıkların yayılışı: İklim değişikliğine ve küresel ısınmaya bağlı olarak birçok ölümcül hastalığı insandan insana veya hayvandan insana bulaştıran ve vektör olarak tanımlanan canlıların (sivrisinekler ve keneler başta olmak üzere) yaşam alanları değişmiş ve genişlemiştir. Bu durumda beraberinde taşıdıkları hastalıkların yayılma alanları da genişlemiş, daha öncesinde görülmeyen bölgelerde de görünür hale gelmiştir.

\section{c. Antibiyotiklere karşı direnç oluşumu:} Bilinçsiz ve aşırı kullanımın bir sonucu olarak günümüzde, mevcut antibiyotiklerin hemen hemen hepsine karşı direnç gelişimi meydana gelmiştir. Bu durum, bakteriyel hastalıklara karşı elimizdeki en büyük silah olan antibiyotiklerin, gücünün azalmasına neden olmaktadır.

d. Kitlesel insan göçleri: İnsanoğlu elindeki güçle, enerji kaynaklarını ve yeraltı-yerüstü zenginlikleri kontrol etme çabası uğruna, dünyanın birçok noktasında dramatik insani felaketlerin yaşanmasına yol açmıştır. Ekonomik, siyasal, siber, biyolojik, konvansiyonel, terör, doğrudan veya vekâlet savaşları şeklinde görülen bu mücadeleler; jeopolitik noktada bulunan ülkemizi, yakinen ve çoğu zaman doğrudan etkilemektedir. Kitlesel göç, bu insani felaketlerin sonuçlarından sadece birisi olup, ülkemiz buna her zaman hazır olmak zorundadır.

\section{Sonuç}

Artık dünyada savaşlar farklı boyutlara evrilmektedir. Özellikle biyolojik silahlar, yakın gelecekte en çok konuşulan tehdit unsurlarının başında yer alacak gibi görünmektedir. Çünkü kitlesel imha ve nükleer silahlar, günümüzde birçok ülkenin elinde bulunduğundan ve karşılıklı güçler dengesi olarak caydırıcılığı bulunmaktadır.

Türkiye; Afrika, Avrupa ve Asya kıtalarının kavşak noktasında yer almakta ve bu üç kıtanın arasında köprü konumunda bulunmaktadır. Bu nedenle de birçok avantaja sahip olduğu gibi birçok dezavantaja da sahiptir. Ülkemiz, bu risklerin bilinci ile bölgesinde her zaman, her alanda güçlü ve dinamik bir ülke olmak zorundadır.

Gıda güvenliğini, halk ve hayvan sağlığını tehdit eden biyolojik felaketlere, saldırılara ve hastalıklara karşı en etkin tedbir üretebilecek kuruluşlardan birisi de Veteriner Kontrol ve Araştırma Enstitüleridir. Zira bu kuruluşlarımız, biyolojik ajan, biyolojik tehdit, biyo-güvenlik, biyo-emniyet gibi kavramları yakından bilen ve bu disiplinle çalışan önemli kurumlarımızdır.

SARS-CoV-2 (Covid-19) salgını Veteriner Kontrol ve Araştırma Enstitülerimizin sağlık ve gıda alanlarındaki stratejik önemini gözler önüne sermiştir. Tüm bu gelişmeler ve bilgiler göz önünde bulundurularak, Enstitülerimizin faaliyet alanları dikkate alınmalı, eksikleri hızla tamamlanmalı ve altyapıları yukarıda arz edilen hususlara en iyi cevap verebilecek şekilde iyileştirilmelidir.

\section{Kaynaklar}

1. Bekman M. (1940) Bakteriyoloji enstitülerinin tavazzuhu (İçinde: Veteriner Tarihi), Ankara Basım ve Cildevi, Ankara, 188-198.

2. Beşe M. (1981) Atatürk'ün 100. Doğum yıldönümünde Türk veteriner Hekimliğinin gelişmesine kısa bir bakış, İstanbul, Evrim Ofset, 120.

3. Çizmen F. (1960) Dergimiz ve Enstitümüz Hakkında birkaç söz, Etlik Veteriner Bakteriyoloji Dergisi, Cilt:1 Sayı: 1, 3-9.

4. FAO (1996). Rome Declaration on food Security and World Food Summit Plan of Action, FAO, Rome.

5. FAO and IFAD. (2019) United Nations Decade of Family Farming 2019-2028. Global Action Plan. FAO and IFAD, Rome.

6. Hacioglu S, Dincer E, Isler CT, Karapinar Z, Ataseven VS, Ozkul A, Ergunay K. (2017) A snapshot avian surveillance reveals West Nile virus and evidence of wild birds participating in Toscana virus circulation. Vector-Borne and Zoonotic Diseases, 17(10), 698-708. DOI: 10.1089/vbz.2017.2138

7. Özsoy A. (1962) Etlik Veteriner Bakteriyoloji ve Seroloji Enstitüsünün 1962 yılı Çalışmaları Hakk'ında, Etlik Veteriner Bakteriyoloji Dergisi, Cilt:1 Sayı: 6,427-441.

8. Özsoy A. (1964) Etlik Veteriner Bakteriyoloji ve Seroloji Enstitüsünün 1964 yılı Çalışmaları Hakk'ında, Etlik Veteriner Bakteriyoloji Dergisi, Cilt:2 Sayı: 3-4,137-156.

9. Özsoy A. (1967) Etlik Veteriner Bakteriyoloji ve Seroloji Enstitüsünün 1967 yılı Çalışmaları Hakk'ında, Etlik Veteriner Bakteriyoloji Dergisi, Cilt:3 Sayı: 3-4,137-156.

10. Tarım ve Orman Bakanlığı (TOB) (2020) https://vetkontrol.tarimorman.gov.tr/ Erişim Tarihi: 29.05.2020.

11. Unat E.K. (1976) 18 Şubat 1976 Milliyet Gazetesi, Prof. Dr. Ekrem Kadri http://gazetearsivi.milliyet.com.tr/Arsiv/1976/02/18 Erişim Tarihi: 29.05.2020.

12. UNEP (2016). UNEP Frontiers 2016 Report: Emerging Issues of Environmental Concern. United Nations Environment Programme, Nairobi. 


